ARTICLE

\title{
From Below to Above the Title: The Construction of the Star Image of Barbara Stanwyck, 1930-1935
}

\author{
LINDA BERKVENS, University of Sussex
}

\begin{abstract}
This paper examines the construction of the star image of Barbara Stanwyck from her first role at Columbia studio in 1930, until 1935, when she became a freelance actress. I will focus especially on Stanwyck's status as a female performer and the possible models of womanhood she portrayed. The work she did, and the accompanying publicity, raises questions about female representation, which I seek to address through this research. I will mainly use archival resources such as fan magazines, press books, and studio publicity material, contemporary to the period to examine how Stanwyck's star image was constructed in this period. Traditionally, scholars look at film stars as part of the filmic text. My research method includes the use of other material (publicity, studio documents, etc.) contemporary to Stanwyck, and demonstrates my intention to look at stars and their images from a different angle. This paper challenges the traditional way of looking at stars as fetishised objects, instead moving toward a more practical examination of the construction of the female star image.
\end{abstract}

\section{KEYWORDS}

Star image; Barbara Stanwyck; classical Hollywood; female representation

\section{Introduction}

Over the past twenty years, film studies' scholarship has favoured certain approaches to the study of stardom, most notably textual analysis of star images. However, more recent scholarly research emphasises the processes of fame and celebrity, and has begun studying film stars not as objects, but as part of the labour process that produces films. This approach recalling Danae Clark's (1995) notion of the 'actor as worker' - is relatively new and takes the star down from the pedestal he or she is traditionally put on when being analysed, i.e. he or she is no longer 'simply' a fetishised object, but part of the workforce that produces the meaning of a film. By looking at the production of a star image, I hope to recount how the changing images related to the star's popularity at specific points in time. Changes in American society, and especially the position of women in that society, often correspond with changes and audience interest in the actresses' images. Feminist film scholar Jackie Stacey argues that Hollywood female stars deserve further attention from film scholars: 'Little attention then, has been paid to female film stars by feminist film scholars except in terms of 
how the stars function within the text' (1994, p.11). Therefore, I will examine not just film texts, but also other primary materials (such as studio documents, publicity material and fan magazines) contemporary to the female star in question (in this case, Barbara Stanwyck). By analysing studio contracts and publicity, fan magazines and newspaper articles, I seek to investigate how the image of Stanwyck was created and what models of femininity she offered her fans. What image did the studios create for her? How was this image represented in (fan) magazines and trade papers? What happened to Stanwyck's image when she went freelance? How did this change fan magazines discourse about Stanwyck? Besides studio discourse, a large part of my investigation is based on fan magazine discourses. Anne Morey states that fan magazines are useful for studying stardom because they 'represent a window into a complex audience-industry relationship' as a 'dialogue' between fans and the industry (2002, p.336). Through this dialogue, we can discover how fan magazines (and other popular discourses) saw and interpreted the image of Stanwyck.

My doctoral thesis is based on case studies of Olivia de Havilland and Barbara Stanwyck, who both achieved prominence in the 1930s, and who had contrasting images during their careers. For this paper, I focus solely on Stanwyck's early star image and look in detail at the initial construction of her star image and the gendered social meanings the image conveys. I will focus on both filmic texts and primary materials contemporary to the actress and thus create a new perspective on the analysis of a star image. By examining Stanwyck's star image, I will explain how star images were created, promoted, and sold to the public. The way the images were constructed (by the actress herself, by agents, by studios, by magazine editors, etc.) should offer an explanation as to why Stanwyck offered certain models of femininity or womanhood in the period 1930-1935. Rather than producing a blow-by-blow account of how Stanwyck's star image was constructed and sold in those first six years, I will focus on specific texts to delineate several themes that mark this discourse over time: her 'emotional acting ability' and her role in Frank Capra's films, the Warner Bros.' vice films, and her marriage to and divorce from vaudeville star Frank Fay.

After her quick rise to stardom in the first part of the 1930s, Stanwyck freelanced most of her career, an unusual thing to do, especially for an actress in the mid-1930s when most actors and actresses were under a long-term contract with a major studio. In this context, freelance is to be understood as not being under an exclusive long-term contract with one studio. It can, however, include non-exclusive, short-term contracts, or non-exclusive contracts for an $\mathrm{x}$ number of pictures for a particular studio. As a freelance actress, Stanwyck had to be very conscious of her star image because she did not have a studio to make career and imagerelated decisions for her. Her freelancing during the heyday of contracts reflects her popularity with audiences, because if she had not been well-liked, studios would not have taken a risk by casting her, when they had enough talented and popular players in their own stable of stars. Stanwyck received Academy Award nominations for Stella Dallas (1937), Ball of Fire (1941), Double Indemnity (1944), and Sorry, Wrong Number (1948). She never won an Oscar for these performances, which could possibly be attributed to the fact that she did not have a studio behind her to promote her in the run up to the awards. This also affected freelance actors like Cary Grant, Rosalind Russell, and Irene Dunne. Even though her film career diminished from the late 1950s onward, she still worked more than former studiobound stars like Bette Davis and Joan Crawford, and continued her film career into the 1970s. In the 1960s, Stanwyck could frequently be seen on television in her own television show and in many Western series until the early 1980s. She died in 1990. 


\section{Stanwyck's First Steps in Hollywood}

Barbara Stanwyck was born Ruby Stevens. At nineteen, she became an actress in the legitimate theatre, where her name was changed to Barbara Stanwyck, the name that would not be changed by Hollywood studio executives. There is more than one story about who was responsible for Stanwyck's name change. Most sources state it was either director Willard Mack (of Stanwyck's first Broadway play The Noose) or David Belasco (Madsen 1994, p.26). Unlike the names of many Hollywood stars who had their names changed by their studio, Stanwyck's 'original name' hardly comes up in what Jane Gaines calls the 'decomposition stage' of their star image - when the 'original name' and persona are being turned into the star persona the studio has in mind for that particular actor or actress (cited in Fowles 1992, p.234). However, it comes up more often in later publications and very prominently in the film The Stork Club (1945). Probably because Stanwyck's name had been changed before she started in Hollywood and she had already made a minor career with her name in the legitimate theatre, it was treated as her 'original name' and there were therefore fewer references to the name, Ruby Stevens. Stanwyck starred in two productions in the legitimate theatre in New York, (The Noose (1926) and Burlesque (1927)). She received good reviews as an actress (Variety 27 October 1926, p.94, Madsen 1994, p.27). In 1928, she married 'Broadway's favourite son,' vaudevillian Frank Fay.

The coming of sound in 1927 and the rapid transition from silent to sound films brought certain problems with it. One problem was that the studios needed actors that could act with their voice, rather than through miming. Many stage performers went to Hollywood to fill the places of former silent actors, whose voices were not suitable for recording. The studios' stock companies expanded rapidly. In March 1929, Frank Fay and Barbara Stanwyck moved to Los Angeles, after Fay had been offered a contract with Warner Bros. (Variety March 26, 1929, p.6). Since both performers came from the stage and thus had experience in acting with their voices, they were interesting for the studios that were looking for new talent for sound films.

Unlike many major Hollywood film stars, Stanwyck was not confined to playing a large number of bit parts before she performed in a starring role. When a new actress was signed to a major studio, she was often cast in various bit parts in a variety of roles so that the studio could decide what type she would be and in which genre or role the audience preferred her (McDonald, 2000, p.43). She is therefore also rarely seen in the typical, almost 'anonymous' advertisements for clothing, makeup and other consumer goods in which most starlets featured. After roughly three pictures, she became Columbia's top female feature player (at this point in time Columbia did not have any stars of its own), and within two years she reached stardom at Columbia studio. Stanwyck's career began in 1929 with a one-picture contract for United Artists for The Locked Door (1929), followed by one picture for Columbia, entitled Mexicali Rose (1929). Because Stanwyck was under one-picture contracts that gave both studios the opportunity to decide whether she had star potential, the studios could not be bothered to start a publicity campaign that would single out Stanwyck's appearance in the films in any way. However, Stanwyck had become a minor celebrity in the New York legitimate theatre, and she was not completely unknown to critics and journalists in Hollywood. Early mentions of Stanwyck in Variety in 1929 relating to the productions of The Locked Door and Mexicali Rose, refer to Stanwyck as 'Barbara Stanwyck, from legit' (9 October 1929, p.13). This status 'from legit' already implied to the reader that the actress had been acting on the 'serious' stage and was thus a 'proper' actress compared to performers from not-so-well-regarded stage forms, such as burlesque. 
During the pre-Hays Code era, or until about 1934, Stanwyck made roughly two kinds films that she would be associated with: Frank Capra's reformation-of-the-heroine films, and Warner Bros.' vice films. Stanwyck's next film after Mexicali Rose was Ladies of Leisure, in 1930, directed by Capra. This film would make her one of the most hot, new properties in Hollywood. After her success in Ladies of Leisure, Stanwyck signed a contract with Columbia for another three pictures. However, Stanwyck signed a non-exclusive contract with the studio, instead of a standard seven-year non-exclusive contract, which meant that she could also negotiate with other studios, and she accepted an offer from Warner Bros. She signed a one-picture deal, followed by a five-year non-exclusive contract, which not only gave her a higher salary $(\$ 175,000$ per year), but also star billing and story approval for all her films (Sharing Agreement 1 March, 1930, p.5, Barbara Stanwyck contract dated 29 September 1930 Warner Bros. legal files at Warner Bros. Archive, USC). She thus had two studios starting a publicity build-up for her. This is also the reason why she is associated with different kinds of pictures in this period and possibly why we can find a number of paradoxes in her star image, such as her acting ability/stardom versus family life.

\section{Frank Capra, Acting, and Family Life}

In the early 1930s, both Warner Bros. and Columbia were studios that relied on standard story formulas, whereas the other three major Hollywood studios relied on prestige films to differentiate themselves (Sklar and Zagarrio, 1998, p.15). The standard story formulas lent themselves excellently for economical film production. During the Depression, Columbia turned out mostly B-pictures and double-bill features, films that were fast and cheap to make. In 1932, Columbia saw the birth of the 'Capra unit' on its lot. Frank Capra was the most important director at Columbia in the early 1930s and his films were the studio's most valuable ones. These films were therefore publicised as widely as a Columbia film-budget would allow. So when one compares the advertisements for Ladies of Leisure in Variety to advertisements from a major studio such as MGM, one difference is noticeable right away. MGM usually advertised multiple pictures in one advertisement, while Columbia advertised one picture per advertisement. So although, for example, Joan Crawford was a major star at that time, she would be briefly named as the star of a certain film in a list of four or five films in the advertisement, while Stanwyck would be featured in a one-page ad for a particular film, thus exposing her more to the public.

The Capra-Stanwyck films of this period prominently featured women 'of independent will' a character that in modern sources is said to have fit Stanwyck's own character (Sklar and Zagarrio 1998, p.42, McBride 1992, p.210). These films - in which a poor and immoral heroine stood alone in the world and went from rags to riches because the wealthy, respectable man she used to rise in class uncovers her moral side - were very popular during the Depression. Americans struggled with hardships, and Stanwyck's characters were just the escapism the audiences needed, the independent girl who overcame all difficult situations. Capra's female heroines can be seen as good girls who are mislead, but are reformed by loving men. Capra's heroines were figures on the social margin, a party girl or a fake evangelist, even if they were from the respectable lower middle class. The characters were based on the 'new women' of the 1920s, women who went outside the house to find jobs, longed to change their social status, and who lived on their own (Staiger 1995, p.9).

In a 'star interview' in the press book for Ladies of Leisure, Stanwyck is quoted as saying that her rise to stardom was all pure luck, moving from chorus girl to legitimate stage actress 
to up-and-coming film star (Ladies of Leisure, 1930). This 'road to stardom' story was an often-used strategy by studio publicity departments. Stardom was usually said to be achieved through luck, being somewhere at the right time and place (such as Lana Turner's story of being discovered at Schwab's drugstore), although it was also always noted that the star already possessed the qualities he or she was famous for, but it took that bit of luck to be able to demonstrate these qualities and to rise to fame. This is what Albert McLean terms the myth of success: 'The general meaning of the myth of success is that American society (...) is open for anyone to get to the top, regardless of rank' (Dyer 1998, p.42). The myth of success echoes the America Dream, the rags to riches story, and the idea that stars are really just ordinary people, only with star quality and a lot more money.

There are very few articles about Stanwyck in popular press and fan magazines in 1930, the year when Ladies of Leisure was released. This is not surprising, since one box office hit does not turn an actor into a remaining star. The following year Stanwyck made five more films, and there is a noticeable increase in the number of articles about her in trade papers and in fan magazines. Most articles in fan magazines focus on her astronomic rise to stardom after Ladies of Leisure and her 'emotional acting ability'. In the Capra-vehicles, Stanwyck portrayed heroines whose, in Joseph McBride's words, 'hardened exterior serves as a protective covering for [their] basic tenderness' (1992, p.163). These roles were an outlet for what critics began to call Stanwyck's 'emotional acting' ability. Stanwyck underplayed an emotional scene, rather than overplayed it. Underneath a one-page portrait in Photoplay of September 1930, the by-line reads: 'Probably the most highly praised young actress of the last few months - Barbara Stanwyck, who shot to emotional stardom on the strength of her unforgettably beautiful and moving performance in 'Ladies of Leisure.' This office is bombarded with letters praising her beauty and acting power' (Griffith 1971, p.19). Film reviews and other articles written during and after Stanwyck's career mention the fact that she is 'so exquisitely natural' and has such 'dramatic ability' (undocumented clippings, production files Illicit and Ladies They Talk About, Warner Bros. Archive, Los Angeles). While reviews for Ladies of Leisure were mixed, Stanwyck received positive reviews. Variety noted that she saved the picture with 'her ability to convince in heavy emotional scenes' (28 May 1930, p.35). It is this definition of 'emotional acting ability' that critics used to describe Stanwyck's acting, and which has been used all through her career ever since. Stanwyck underplayed the emotions, rather than overplayed through the use of wild gestures or hysteric cries. The way she conveyed the necessary emotions seemed more natural than over-acted hysterics. Especially in recent publications, such as (auto)biographies of Stanwyck (DiOrio, 1984) and Capra (Capra, 1971), or a book detailing the production of their final collaboration Meet John Doe (1941) (Wolfe, 1989), Stanwyck's emotional acting ability is more clearly defined and explained as above.

After the transition to sound, filmmaking changed. For actors, this meant that they now had to act with their voice, as well as with their body and face. Before sound was introduced, actors relied on large gestures and especially facial expressions to convey their emotions to the audience. The emphasis was no longer on demonstrating the emotion, but suggesting them. Especially in her first two films with Capra, Stanwyck's theatre background is still visible in some of her too=large gestures and movements, but Capra's use of her close-ups, with special diffusion lenses, shows Stanwyck's minimal facial expressions, which convey the 'naturalness', or authenticity mentioned by critics and writers. An example of this is the breakfast scene of Ladies of Leisure, when Stanwyck's character, Kay, has just made breakfast for the painter (played by Ralph Graves) - for whom she is posing and with whom she has fallen in love - who is hiding behind a newspaper, completely ignoring her staring at him. Her face goes from a large, loving smile, into a trembling, fake attempt to attract his 
attention by trying to catch breadcrumbs in her mouth, to a flood of tears. In a similar key scene in the same film, we see Stanwyck's face go from anxiety (scared that the painter will assault her when she spends the night on his couch) to a loving smile when she discovers that the painter has no intention to treat her in an indecent way. For some reason, which I believe is difficult to describe as it is impossible to know exactly how an actor comes to his or her performance by just watching them, audiences saw Stanwyck's acting as natural, as coming from within her, in opposition to the mannered, or directed acting that some actresses displayed (for example Davis, and later De Havilland in comedy films). This 'mannered' acting is often associated with what Karen Hollinger refers to as star acting, 'playing oneself in each role' (2006, p.47). Here, the 'star is always himself or herself, but just disguised as a character' (Maltby 2003, p.384). This form of acting is called personification. It has become identified with the Hollywood star system, where the notion was that stars did not act, but merely played themselves on the screen. The most attractive part of stars to the audience during the studio system was the continuity of the stars' image; this guaranteed the audience a particular quality of film experience (King 1986, p.167). However, Stanwyck's acting is being described as 'natural' or 'emotional' and these notions often refer to the natural acting style that is associated with Method acting, where the actor 'disappears' into the character, rather than a star playing himself/herself on the screen.

I am not going to discuss acting styles here, that would be a whole new paper in itself, but I want to mention the fact that Stanwyck's acting was something that was picked up by critics and audiences and that has always been an important element of her star image. Her natural way of acting also fed into the (later) notion that Stanwyck was 'authentic' as a star. The acting, the articles detailing Stanwyck's 'naturalness' and the lack of glamour that was usually associated with stardom in her so-called private life, all contributed to the public's idea that Stanwyck was ordinary, that she was off-screen what she seemed to be on-screen. Her performance was seen as an expression of her true self (Dyer 1998, p.21). It is interesting that Stanwyck's craftsmanship is foregrounded in her star image, since in the 1930s and 1940 s, the audience's attention was focused on the star's personality, rather than his or her craftsmanship (Baron 2004, p.83).

Ladies of Leisure had made Stanwyck a popular actress in Hollywood and her collaboration with director Capra was promising for both. Stanwyck was a natural actress, a trait that is commented on and praised, from her first review until her last. As a natural actress, Stanwyck acted more by instinct than by calculation (which does not automatically give her the 'emotional acting ability,' but the two terms are related). In Capra's films she could use this ability to portray his heroines, stripped away from falseness, so that the audience could take both character and actress to heart. Reviews and articles raved about Stanwyck and her natural acting ability, which was also emphasised in the press book for the film (Variety 28 May 1930, p.35, Ladies of Leisure 1930).

Capra and Stanwyck's second collaboration was The Miracle Woman in 1931. The Miracle Woman firmly established Stanwyck as a film star. Stanwyck had the lead role and the film did fairly well at the box office, thus demonstrating that she could carry an entire picture on her own. The press book for The Miracle Woman promoted the film as Stanwyck's 'Greatest Dramatic Role' and as 'Incomparable Actress In Her Greatest Role', again foregrounding Stanwyck's acting ability in her star image (The Miracle Woman, 1931). After the success of The Miracle Woman (meaning that she was not just a one-day fly), the press became more interested in Stanwyck's private life, largely because her one-time popular husband was no longer popular in Hollywood. Moreover, Frank Fay had become 'Barbara Stanwyck's husband' instead of Stanwyck being 'that girl Frank Fay married' (Albert 1931, p.69). The 
press sniffed marital trouble. Stanwyck faced the press with answers that she would gladly give up her career for Fay if he wanted her to do so (Albert 1931, p.69). Stanwyck's offscreen persona was that of a dedicated housewife and spouse to Fay. Her loyalty to him was overwhelming, according to various articles in Photoplay and Picturegoer where she was often quoted to say: 'I am Mrs. Frank Fay first, and Barbara Stanwyck second' (Albert 1931, p.69). In interviews, Stanwyck repeated that she did not like Hollywood, and that she would follow Fay wherever he went even if that meant giving up her Hollywood career (Albert 1931, p.147). She painted a picture of a blissful little household, all within the lines of what publicity departments liked to see, as star living in a lovely house, with a lovely family. Several pictures of the married couple were supposed to demonstrate that the Fay's were indeed a 'happy couple.' According to Hollywood standards, happiness meant domestic happiness and unhappiness meant domestic failure. Many fan magazines featured articles about the stars' marital happiness, and female stars were always quoted as saying that when the right man would come along, they would give up their careers for domesticity. According to Screen Guide, marital success in Hollywood meant 'career sacrifice, particularly on the part of the wife' (1950 cited in McLean 2004, p.76). However, '[t]here are many actresses who refuse to give up their careers. What about these women? you ask. Are they doomed to spinsterhood or unhappiness?' The particularity here is in the fact that the women are stars and they would not be stars without their careers. It thus means that to be married and a 'proper' woman means giving up stardom. 'Marriage is what makes American adults normal (...), but it is also what makes them the less interesting norm (...), according to Adrienne McLean (2004, p.77), referring to Richard Dyer's dialectic that stars are both ordinary and extra-ordinary at the same time. While everyone can be married (ordinary), but not everyone is a star (extraordinary).

Stanwyck made the ultimate sacrifice as a wife for Fay when she breached her contract with Columbia, in 1931, supposedly because she wanted more money, though most Hollywood columnists suspected a different reason. (Gossip) columnist Louella Parsons suspected that Stanwyck's breach of contract was to disguise the real reason, that it was Fay who demanded to have her with him in New York (DiOrio 1984, p.73). Columnist Harrison Carroll summed up the situation: 'Independent as they make them is Barbara Stanwyck - independent of everybody except Frank Fay' (cited in DiOrio 1984, p.72). An article in Variety claimed that 'Frank Fay is generally supposed to be mixed up somewhere in the fuss', and a few follow-up articles indirectly referred to Fay as the man behind Stanwyck's action to walk out (Barbara Stanwyck 21 July 1931, p.3).

\section{On-screen Immorality and Off-Screen Morality}

During the so-called pre-Code era, Warner Bros. was notorious for 'spicing up' its films. The pre-Code era coincided with the Depression and both admission prices and audience numbers dropped. In order to lure audiences back to the movie theatres, studios started to 'spice up' their films with sexual insinuations and violence. This all worked until the Motion Picture Production Code was strongly enforced in 1934, which forbade excessive violence, illegal drugs, adultery, and more controversial topics. The majority of the characters Stanwyck played in her early Warner Bros. films were all stereotypical bad girls or gold diggers: tough girls who could fend for themselves, crossing all moral borders on their way to rise in class. In this period, Warner Bros. issued a large number of vice films, many of these in a cycle of gold digger films (most notably Baby Face (1933)). Gold diggers used men and transgressed sexual norms in order to gain status and to rise in class (Jacobs 1995, p.11). These bad girls 
became associated with modernism and glamour. Donald Albrecht (see Jacobs 1995, p.57) argues that the glamour in these films had specific narrative function as a metaphor for modernity and the 'new' woman with independence, sexual promiscuity, and feminine selfindulgence. Gold diggers were usually positioned in luxurious art-deco penthouses which contrasted with the traditional 'small-town kitchen,' or domestic ideal, where the 'good woman' was positioned. The display of clothes became highly conventionalised within these films and as Jackie Stacey argues: through the 'purchasing and use of clothing, spectators tale[d] on a part of the star's identity and [made] it part of their own' (1994, p.170).

In December 1931, Variety's front page read, 'Sinful Girls Lead in 1931' (29 December, 1931, p.5). According to the trade paper, public taste had changed from 'heroines on pedestals' to 'glamorous, shameful ladies', and this was to blame for women's taste in films (Sinful Girls 29 December, 1931, p.5, Dirt Craze 16 June, 1931, p.1). The women's films of the pre-Code era offered their female audience illicit romance and passion, but at a safe distance. It showed the sleek lifestyles that women, during the Depression, did not have and could only dream about. According to Jeanine Basinger, Stacey and other contemporary scholars, women could view these 'over-the-top, out-of-control plots' precisely because they were not real (1993 p.6,7). Ruth Morris sums it up as: 'The smug and contended housewife subconsciously envies the glamour that surrounds cinema mistresses. Luxury, excitement, dangerously-stolen romance are an alluring opposition to her own conventional life' (cited in Doherty 1999, p.127).

Stanwyck would largely be associated with these glamorous, sexually-liberated women in her Warner Bros. productions in the pre-code era. Variety noted on 13 May 1931 that Warner Bros. had removed Stanwyck from a scheduled film because she played 'the loose lady too often' (Too Loose 1931, p.3). Until now, she had only done one picture for Warner Bros. that featured a 'loose lady,' and two similar films for Columbia. So while Warner Bros. apparently did not want to promote Stanwyck as a bad girl or a loose lady at this point, they did continue to feature her in similar films, most notably in Night Nurse (1931), Baby Face, and Ladies they Talk About (1933). Warner also issued a series of 'cheesecake' photographs of Stanwyck, something they did for more female actresses, especially in the promotion of vice films. Although the production of cheesecake photographs is not something specifically from this period, the photographs taken during this period are often more risqué than ones from the 1940 s, for example.

Ladies They Talk About is a good example of how studios worked around the Production Code, but would still 'spice up' their films. The advertisements for the film refer to the 'Stanwyck tradition of daring roles' and refer to previous similar roles in Night Nurse and Illicit (1931) (Ladies They Talk About, 1933). The movie poster for the film showed Stanwyck as naked as the Advertisement Code would allow her to be. However, there is no nudity in the film itself. This sort of 'daring' publicity was a trick of the studios to lure audiences to the theatres (Doherty 1999, p.110).

'Men called her Beautiful! Women called her Bad! Police called her Dangerous! You'll call her Wonderful!' This is the final part of the tagline of the trailer for Ladies They Talk About and it refers to the women in the audience for whom this kind of strong, modern woman was their favourite idea of escapism during the Depression (Basinger 1993, p.6). The trailer gives hints towards the 'danger' of the picture - a woman who can use her beauty to conquer men, to take them away from their wives, a woman who defies the law, but these fantasies were apparently exactly what the female audience wanted to see. 
Stanwyck's film So Big! from 1932 is a maternal melodrama and a move away from her other films of the period. So Big! gave Stanwyck an opportunity to play a sacrificial mother rather than a gold digging girl. Maternal roles worked well with female audiences from 1932 onward. The early thirties were the height of the woman's film and from 1932 onward, a maternal character could boost a female star's image. In January 1932, Variety reported that Hollywood's new style was a baby craze: 'Not long ago stars acted out stories to prove that girls should have a career' (Baby Craze, 5 January, 1932, p.1). Apparently Norma Shearer proved that stars could have babies and a career, and that stars, 'who thought they had to be the same kind of creatures off the screen as on ... would [not] break faith with their fans' when they became mothers (Baby Craze, 1932, p.1). Variety noted that 'the public is sticking to the current cycle of motherhood films' and that these pictures 'protect[ed] their stars by glorifying and justifying motherhood' (Baby Craze, 1932, p.1). Private motherhood enhanced stars' popularity. Six months after So Big! was released, Stanwyck and Fay adopted a baby boy, Dion Anthony Fay (Variety 13 December 1932, p. 50). Children meant a good image and posing with Dion for publicity could boost Stanwyck's image as a 'good' woman, i.e. a wife and mother.

Stanwyck maintained her off-screen persona as a dedicated housewife. Because she so often appeared as an immoral girl in her films, Warner Bros.' publicity had to make sure that audiences did not confuse the on-screen character with Stanwyck's off-screen image. Stanwyck's marriage and domestic happiness were therefore exploited to promote her as the opposite of the immoral women she played on screen. Most articles and interviews of this time continued to feature her overwhelming love for Fay, and this was emphasised too much as one of the readers' letters in Photoplay stated: 'She has to quit talking so much about Fay. Why doesn't she emulate the example of (...) Gloria Swanson who, although married several times, still seeks romance (...)?' (Drake 1932, p.10). In 1933, the first rumours of a divorce were spread. Film magazine Motion Classic featured an article about the divorce rumours in its March 1933 issue (Calhoun 1933, p.31), followed by an article that denied the rumours in its April issue (Grant 1933, p.26). Stanwyck strongly contested the rumours in various statements.

\section{A New Beginning}

In 1935, Stanwyck's contract with Warner Bros. ended. Stanwyck became a freelance actress and was thus free to accept offers from any studio, and Variety duly reported on all of the negotiations and role-assignments that Stanwyck had with various studios. If the trade paper was to be believed, Stanwyck would have been appearing in nearly ten pictures in 1935. She only made four pictures in 1935 since she started to freelance. In his current biography about Stanwyck, Al DiOrio suggests that Stanwyck went freelance because her agent and friend Zeppo Marx advised her to do so, so that she would have more control over the roles she could accept (1984, p.87). However, I have not found any 'official' statement by Stanwyck as to why she became a freelance actress. Carman seems to suggest in her article about female stars and independence in the 1930s that Stanwyck did so because she had always, in a sense, been 'independent,' even when under contract (2008, p.591). Compared to comments from recent biographers about Stanwyck's strong-headedness and self-determination, this seems a logical conclusion, albeit not an absolute one. Stanwyck signed a non-exclusive contract to make three pictures for RKO in 1936, after she was very successful in their production Annie Oakley (1935). This Western would be the first of many Westerns that would follow in her long career. In this sense, her freelancing paid off in that she was now able to turn her back on 
the stereotypical roles she was assigned to under her studio contracts. Besides a Western, Stanwyck also added comedy to her repertoire in the film Red Salute (1935). With changes in genres, the characters Stanwyck played changed as well. She no longer played the gold digger or fallen woman, but she now also played a rich general's daughter, a horse trainer, a sharpshooting Western girl, a shop girl, etc.

For freelance stars, a contract became a way to gain more control over their image and gain independence in the studio system. As Jane Gaines notes in her book Contested Cultures, ' $[t]$ he studio used the contract to secure on-screen continuity through provisions for illness and vacations, wardrobe fittings, tardiness on the set ... Stars retaliated with riders modifying wardrobe requirements, stipulating screen billing order and typeface size on the credits, and mandating the number of close-ups per picture' (1991, p.149).

At the same time when Stanwyck began to freelance, she divorced Frank Fay. The 'happy family' image was gone, and the divorce had to be incorporated in Stanwyck's image, it could not be ignored, since a divorce between the two famous people attracted public attention. However, the fact that Stanwyck started a new road in her career as a free-lancer could be combined with the new road she was taking is life, as a single, working woman. A 1936 Photoplay article explains that after the divorce and the studio contracts, there was a 'brand new Stanwyck with a brand new personality', who was now 'more peaceful, and more herself' (Stevens 1936, p.24). This line can be read as a critique of the previous so-called happy marriage, that this was no longer a reference to something authentic, but to a fraudulent representation of truth. The marriage had been a facade, an image, something that hid the 'true Stanwyck'. Fan magazine writers replaced the happy marital bliss with a life of freedom, hard work, and single-motherhood. During the marriage, Stanwyck had been 'unhappy (...) resentful and confused' (Stevens 1936, p.24). After the marriage she was 'brand new' and 'ready to work' (Stevens 1936, p.24). Fan magazines emphasised Stanwyck's independence, both in her career and in her (love) life, and Stanwyck's independence influenced the 'feminine' advice she gave to readers of fan magazines. In an article entitled 'Barbara Stanwyck's Advice to Girls In Love', Stanwyck advised girls not to 'give your life away along with your love...', drawing upon her personal life. She describes her independence as 'living dangerously...' because she lived 'her own life as I please' (italics in original) (Hall). In the following year (1936), these articles continued to feature in fan magazines, where they also more and more incorporated Stanwyck's personal life before she started in the film industry. The Barbara Stanwyck image became more rounded, i.e. it no longer just focused on Stanwyck's current life, but also included her life history before her move to Hollywood as well. However, this 'new road' in Stanwyck's life gives material for a whole new paper (see also Emily Carman's article 'Independent Stardom: Female Film Stars and the Studio System in the 1930s'). The point of mentioning it here, is that after the end of her studio contracts in 1935, Stanwyck's star image changed dramatically from a female domestic ideal - happily married with a son - to being an independent, single, working mother.

\section{Summary}

This paper details the construction of Stanwyck's star image from 1930-1935, from her first contracts at Columbia studio and Warner Bros. until she went freelance. I have looked at the construction of Stanwyck's image by focusing on specific texts that outline particular themes 
which feature prominently in her star image and which convey models of femininity to Stanwyck's audience.

When Stanwyck started her career at Columbia Studios, her on-screen image was largely connected to her performances of tender heroines in Capra's films about American society. Her off-screen persona fitted in with these roles, because in 'real life' Stanwyck had found 'perfect' domestic bliss. Following her career at Columbia, Stanwyck went to Warner Bros., where she mostly portrayed so-called loose ladies on the screen. To make sure that the audience did not confuse Stanwyck's on-screen image with her off-screen image, her offscreen image was dominated with Stanwyck and Fay's marital happiness. And at the same time, when it became a 'fashion' for Hollywood female stars to have babies, Stanwyck appeared less in gold digger films, but also added the maternal melodrama to her list of films. She and Fay also joined the 'baby craze' when they adopted a baby boy in 1932 .

The reviews for Stanwyck's second Columbia film Ladies of Leisure noted her 'emotional acting ability'. This notion meant that Stanwyck was a 'natural' actress, who was able to convince, and take to heart, her audience in heavy emotional scenes. In reviews for films that followed, as well as in the films' press books, this dramatic ability was often foregrounded. It is interesting that Stanwyck's craftsmanship was an important element in her star image (through her whole career), when studio publicity in the 1930s and 1940s usually focused on stars' personalities, rather than their acting ability.

After Stanwyck's contracts with Warner Bros. and Columbia ended in 1935, she went freelance. This was an extra-ordinary thing to do, especially for a woman, as there were more male freelancers than female freelancers in the era of long-term, exclusive studio contracts. Becoming freelance meant that Stanwyck now had her star image in her own hands (together with her agent, of course) and that she had to be extra conscious about her choice of roles. She directly turned to roles that were different from the ones she was assigned to at the studios. At the same time, Stanwyck divorced Fay, and this divorce became a part of Stanwyck's star image. Publicity stories no longer wrote about Stanwyck's happy marriage, but about her courage as a single, working mother, and the new road that her life and career were taking now. So during her studio contracts, Stanwyck's off-screen persona was that of a dedicated housewife and mother, a domestic ideal, but when the end of her studio contract and her divorce coincided, fan magazine writers and studio publicity writers could incorporate the two events to begin a 'new' star image for Stanwyck. One of an independent, hard working woman - an image that would last for nearly the rest of her career.

\section{References}

Albert, K., (1931) She has Hollywood's Number. Photoplay, Vol. 40 pp.6, 147-148.

Baby Craze... Newest Style in Hollywood. (1932) Variety, 5 Jan. p.1.

Barbara Stanwyck and Columbia Jammed Up By Girl's Defiance. (1931) Variety, 21 July p.3.

Baron, C., (2004) Crafting Film Performances: Acting in the Hollywood Studio Era. In: Robertson Wojcik, P., (ed.) Movie Acting, The Film Reader. London: Routledge pp.83-94.

Basinger, J., (1993) A Woman's View: How Hollywood Spoke to Women 1930-1960. New York: Chatto \& Windus. 
Burlesque. By G. Manker Watters and A. Hopkins (1927). Play. 1 September 1927 - July 1928. Plymouth Theater, New York.

Performers: H. Skelly, B. Stanwyck, O. Levant. Director: A. Hopkins.

Calhoun, D., (1933) Divorce rumors. Movie Classic. Vol. 4 p.31.

Capra, F., (1971) The Name Above the Title: An Autobiography. New York: MacMillan.

Carman, E.S., (2008) Independent Stardom: Female Film Stars and the Studio System in the 1930s. Women's Studies. Vol. 37 pp.583-615.

Clark, D., (1995) Negotiating Hollywood: The Cultural Politics of Actors' Labor.

Minneapolis: University of Minnesota Press.

DiOrio, A., (1984) Barbara Stanwyck. New York: Coward-McCann.

Dyer, R., (1998) Stars. New ed. London: British Film Institute.

Dirt Craze Due to Women. (1931) Variety 16 June p.1.

Doherty, T., (1999) Pre-Code Hollywood: Sex, Immorality, and Insurrection in American Cinema 1930-1934. New York: Columbia University Press.

Drake, M., (1932) Letter. Photoplay, Vol. 41 p.10.

Fowles, J., (1992) Starstruck: Celebrity Performers and the American Public. Washington: Smithsonian Institution Press.

Gaines, J.M., (1991). Contested Culture: The Image, the Voice, and the Law. Chapel Hill: University of North Carolina Press.

Grant, J., (1933) Divorce rumors denied._Movie Classic, Vol. 4 p.26.

Griffith, R., (1971) The Talkies: Articles and Illustrations from Photoplay Magazine 19281940. New York: Dover Publications Inc.

Hall, Gladys. Barbara Stanwyck's Advice To Girls In Love. Carbon copy found in the Gladys Hall Papers, folder 441, in the Margaret Herrick Library.

Hollinger, K., (2006) The Actress: Hollywood Acting and the Female Star. Milton Park: Routledge.

Jacobs, L., (1995) The Wages of Sin: Censorship and the Fallen Woman Film, 19281942.Madison: University of Wisconsin Press.

King, B., (1986) Stardom as an Occupation. In: Kerr, P., (ed.) The Hollywood Film Industry.London: Routledge \& Kegan Paul.

Ladies of Leisure. (1930) Columbia Pictures. Press book.

Ladies They Talk About. (1930) Warner Brothers Pictures. Press book.

Madsen, A., (1994) Stanwyck. New York: HarperCollins Publishers, Inc.

Maltby, R., (2003) Hollywood Cinema. 2nd ed. Malden: Blackwell. 
McBride, J., (1992) Frank Capra: The Catastrophe of Success. London: Faber and Faber.

McDonald, P., (2000) The Star System: Hollywood's Production of Popular Identities. London: Wallflower.

McLean, A.L., (2004) Being Rita Hayworth: Labor, Identity, and Hollywood Stardom. New Brunswick: Rutgers University Press.

The Miracle Woman. (1931) Warner Brothers Pictures. Press book.

Morey, A., (2002). So Real as to Seem Like Life Itself: The Photoplay fiction of Adela Rogers St. John. In: Bean, Jennifer M. and Negra, D., (eds.) A Feminist Reader in Early Cinema. Durham: Duke University Press pp.333-346.

The Noose. By W. Mack (1926). Play. 20 October 1926 - April 1927. Hudson Theater, New York. Performers: L. Lonergan, A. Shoemaker, B. Stanwyck. Director: W. Mack.

Schuster, M., (1976) Motion Picture Performers: A Bibliography of Magazine and Periodical Articles. Supplement no. 1 1970-1974. Metuchen: The Scarecrow Press.

Sharing agreement by Col-WB on Stanwyck. (1930) Variety, 1 Mar. p.5.

Sinful Girls Lead in 1931. (1931) Variety, 29 Dec. p.5.

Sklar, R. and Zagarrio, V., (1998) Frank Capra: Authorship and the Studio System. Philadelphia: Temple University Press.

Stacey, J., (1994) Star Gazing: Hollywood Cinema and Female Spectatorship. London: Routledge.

Staiger, J., (1995). Bad Women: Regulating Sexuality in Early American Cinema. London: Routledge.

Stevens, G., (1936) Dinner For One, Please, Johns. Photoplay, Vol. 49 pp.24-25, 90.

Too Loose - Barbara's Out. (1931) Variety, 13 May p.3.

Wolfe, C., (ed.) (1989) Meet John Doe: Frank Capra, Director. (s.l), Rutgers University Press.

\section{Filmography}

Annie Oakley. (1935) Film. Directed by George Stevens, USA, RKO Radio Pictures.

Baby Face. (1933) Film. Directed by Alfred E. Green, USA, Warner Bros. Pictures.

Ball of Fire. (1941) Film. Directed by Howard Hawks, USA, RKO Radio Pictures.

Double Indemnity. (1944) Film. Directed by Billy Wilder, USA, Paramount Pictures.

Illicit. (1931) Film. Directed by Archie Mayo, USA, Warner Bros. Pictures.

Ladies of Leisure. (1930) Film. Directed by Frank Capra, USA, Columbia Pictures. 
Ladies They Talk About. (1933) Film. Directed by Howard Bretherton and William Keighley, USA, Warner Bros. Pictures.

Ladies They Talk About. (1933) Trailer. USA, Warner Bros. Pictures.

The Locked Door. (1929) Film. Directed by George Fitzmaurice, USA, United Artists.

Meet John Doe. (1941) Film. Directed by Frank Capra, USA, Warner Bros. Pictures.

Mexicali Rose. (1929) Film. Directed by Erle C. Kenton, USA, Columbia Pictures.

The Miracle Woman. (1931) Film. Directed by Frank Capra, USA, Columbia Pictures.

Night Nurse. (1931) Film. Directed by William A. Wellman, USA, Warner Bros. Pictures.

Red Salute. (1935) Film. Directed by Sidney Lanfield, USA, United Artists.

So Big! (1932) Film. Directed by William A. Wellman, USA, Warner Bros. Pictures.

Sorry, Wrong Number. (1948) Film. Directed by Anatole Litvak, USA, Paramount Pictures.

Stella Dallas. (1937) Film. Directed by King Vidor, USA, United Artists.

The Stork Club. (1945) Film. Directed by Hal Walker, USA, Paramount Pictures. 